\title{
Inflammatory Breast Carcinoma in a Developing Community
}

\author{
Wilson Onuigbo IB* \\ Department of Pathology, Medical Foundation and Clinic, Nigeria
}

Submission: May 22, 2017; Published: August 03, 2017

*Corresponding author: Wilson Onuigbo IB, Department of Pathology, Medical Foundation and Clinic, 8 Nsukka Lane, Enugu 400001, Nigeria, Email: wilson.onuigbo@gmail.com

\section{Abstract}

In the landmark monograph, "Tumors of the Breast," published by the Armed Forces Institute of Pathology way back in 1968, Figure 80 exemplified Inflammatory Carcinoma. The points were made that

(i) The lesion is not a purely histologic one but rather one made on clinical presentation as well and

(ii) Only 30 biopsy materials were available.

Accordingly, in this paper, the author has dwelt on 33 cases diagnosed personally at a Reference Pathology Laboratory situated at Enugu the capital of the Eastern Region of Nigeria in which the Ibos or Igbos are the Ethnic Group domiciled in it. In sum, it is deemed sufficient to portray this pictures que tumor by way of capturing a dozen reports as well as one case in which 3 succeeding biopsies became available. It is concluded that the diagnosis of inflammatory breast carcinoma sufficiently depends on intimate relationship between cancer cells and inflammatory cells found with the help of a biopsy service available to doctors working in a developing community.

Keywords: Breast; Biopsy; Cancer; Inflammatory type; Ethnic group; Developing community

\section{Introduction}

The famous Armed Forces Institute of Pathology produced "Tumors of the Breast in 1968 [1]. It is noteworthy that an Inflammatory type was carved out. In particular, the very language employed in the descriptions of local cases was picturesque. Moreover, one case presented thrice peculiarly.

\section{Case Examples}

1. H 2399/85. Much of the tissue is fat but there is an area which at first sight is inflammatory. However, among the inflammatory infiltrates, especially in one of the two random sections examined, there are highly mitozing, deeply hyperchromatic tumour cells growing singly or in small groups.

2. UH 231/88. At first sight, the appearances are inflammatory. However, in the midst of such exudates, there are tumour cells which are pleomorphic in parts, giant cells abounding.

3. 051182. The appearances are strikingly inflammatory with underlying epithelial malignancy.

4. UH 448/90. There are mitotically active spheroidal cells in the midst of inflammatory cells in almost disguised fashion.

5. 92085. An inflammatory overlay is noteworthy. However, cancer cells abound in parts and evoke considerable stromal response.

6. 930645. Much of the sections are deceptively inflammatory with some necrosis. However, tumour cells show up with considerable hyperchromatism, pleomorphism and mitotic activity in parts.

7. 9308123. The appearances are a close interrelationship between malignancy and inflammation.

8. 9501182. Epithelial cancer cells grow in intimate association with inflammatory cells.

9. 950820. Tumour cells are rather hyperchromatic and pleomorhic and tend to be intimately mixed with inflammatory cells.

10. 950825. It is evident that there is an intimate mixture of epithelial cancer cells and dense inflammatory infiltrates. 
11. 9709117. Mammary parenchyma shows pressure atrophy on account of malignant epithelial growth whose stroma manifests lymphocytes so strikingly as to simulate mere inflammation.

12. 0107149. There is epithelial malignancy which is almost hidden by inflammatory response.

\section{Peculiar Case}

A woman was aged 40 years when first seen. There were three visits altogether, inflammatory carcinoma was repeatedly diagnosed as follows.

a. 20/9/1994 - 9409137. Inflammatory cells are discernible. Moreover, there are pleomorphic hyperchromatic cells scattered in parts.

b. 20/6/1995 - 9506111. "Mitotically active tumour cells are seen to lie loosely in the midst of inflammatory cells without differentiation.

c. 10/11/1995 - 951157. Skin is ulcerated and undermined by a growth characterized by admixture of tumour cells and inflammatory cells.

\section{Discussion}

This particular case lasted over a year. Moreover, it was not associated with skin changes. This contrasts with the view [2] of inflammatory carcinoma being so named because of its clinical presentation- an erythematous and swollen breast of rapid onset. In this context, it is also said to be characterized by the clinical appearance of inflammation, with edema and redness of the breast [3]. Or, as was viewed elsewhere [4], "patients present with rapid onset of erythema and edema of the breast skin". Because of its rarity, inflammatory breast cancer (IBC) is "often misdiagnosed as mastitis or generalized dermatitis" [5]. Little wonder that "the diagnosis is based on clinical inflammatory signs and is reinforced by pathological findings" [6]. Interestingly, one group [7] opted for confirmation of true IBC on "pathological demonstration of dermal lymphatic emboli or extensive lymph-node involvement."

It seems to me that one does not need to wait for lymph-node metastases to occur let alone for the identification of emboli in the lymphatics. I am persuaded that the intimacy or admixture of both cancer cells and inflammatory cells suffices. It is not surprisingly, therefore, that a group proposed the identification of an "inflammatory signature" [8].

During the 1970's, there were the opposing views of IBC being "a clinical diagnosis" [9] or "as a "pathologic entity [10]. Certainly, none of my cases was correctly diagnosed clinically. Therefore, they join other data from countries as diverse as UK [11], Belgium [12], France [13], Egypt [14], United Arab Emirates [15], and USA [16] from which IBC was presented. Perhaps, one should end with the hope expressed by Woodward and Cristofanilli [17] thus Inflammatory breast cancer (IBC) represents the most virulent form of breast cancer, characterized by involvement of the skin and rapid progression of the disease. Management involves careful coordination of all multidisciplinary modalities, including imaging, systemic chemotherapy, surgery, and radiation therapy. The use of neoadjuvant chemotherapy has contributed significantly to improvement in overall survival since the first descriptions of this entity and has made the role of locoregional therapy, including surgery and radiation critical to continued improvements in this disease.

\section{References}

1. Dirit Mc RW, Stewart FW, Begg JW (1968) Tumors of the Breast. Armed Forces Institute of Pathology, Washington DC, USA, p. 101.

2. Li BD, Sicard MA, Ampil F, Abreo F, Lilien D, et al. (2010) Trimodal therapy for inflammatory breast cancer: A surgeon's perspective. Oncology 79(1-2): 3-12.

3. Anderson WF, Schairer C, Chen BE, Hance KW, Levine PH (2005) Epidemiology of inflammatory breast cancer (IBC). Breast Dis 22: 9-23.

4. Yamauchi H, Woodward WA, Valero V (2012) Inflammatory breast cancer: What we know and what we need to learn. Oncologist 17(7): 891-899.

5. Robertson FM, Bondy M, Yang W (2010) Inflammatory breast cancer: the disease, the biology, the treatment. CA Cancer J Clin 60(6): 351375 .

6. Lerebours F, Bieche I, Lidereau R (2005) Update on inflammatory breast cancer. Breast Cancer Res 7: 52-58.

7. Bonnier P, Charpin C, Lejeune C, Romain S, Tubiana N, et al. (1995) Inflammatory carcinomas of the breast: A clinical, pathological, or a clinical and pathological definition? Int J Cancer 62(49): 382-385.

8. Charafe-Jauffret E, Tarpin C, Bardou VJ, Bertucci F, Ginestier C, et al. (2004) Immunophenotypic analysis of inflammatory breast cancers: identification of an 'inflammatory signature'. J Pathol 202(3): 265-273.

9. Droulias CA, Sewell CW, Mcsweeney MB, Powell RW (1976) Inflammatory carcinoma of the breast: A correlation of clinical, radiologic and pathogic findings. Ann Surg 184(2): 217-222.

10. Ellis DL, Teitelbaum SL (1974) Inflammatory carcinoma of the breast. Cancer 33(4): 1045-1047.

11. Lee AHS, Dublin EA, Bobrow LG (1999) Angiogenesis and expression of thymidine phosphorylase by inflammatory and carcinoma cells in ductal carcinoma in situ of the breast. J Pathol 187(3): 285-290.

12. Colpaert CG, Vermeulen PB, Benoy I, Soubry A, van Roy F (2003) Inflammatory breast cancer shows angiogenesis with high endothelial proliferation rate and strong E-cadherin expression. Br J Cancer 88(5): 718-725.

13. Labidi Si, Mrad K, Mezlini A, Ouarda MA, Combes JD, et al. (2008) Inflammatory breast cancer in Tunisia in the era of multimodality therapy. Ann Oncol 19(3): 473-480. 
14. Mohamed MM,Ai-Raawi D, Sabet SF, El-Shinawi M (2014) Inflammatory breast cancer: New factors contribute to disease etiology: A review J Advanced Res 5(5): 525-536.

15. Dawood S, Cristofanilli M (2011) Inflammatory breast cancer: what progress have we made? Oncology (Williston Park) 25(3): 264-273.
16. Dushkin H, Cristofanilli M (2011) Inflammatory breast cancer. J Natl Compr Canc Netw 9(2): 233-240.

17. Woodward WA, Cristofanilli M (2009) Inflammatory breast cancer. Semin Radiat Oncol 19(4): 256-265.

\section{Your next submission with Juniper Publishers} will reach you the below assets

- Quality Editorial service

- Swift Peer Review

- Reprints availability

- E-prints Service

- Manuscript Podcast for convenient understanding

- Global attainment for your research

- Manuscript accessibility in different formats ( Pdf, E-pub, Full Text, Audio)

- Unceasing customer service

Track the below URL for one-step submission https://juniperpublishers.com/online-submission.php 